\title{
The Relationship Between Leadership Style \& Demographic Characteristics Of Taiwanese Executives
}

Hsin Kao

Annette E. Craven, (Email: craven@uiwtx.edu), University of the Incarnate Word

Thun-Yun Kao, (Email: tykao@mail.tku.edu.tw), Tamkang University, Taiwan

\begin{abstract}
The purpose of this study was to investigate the relationship between Taiwanese executives' leadership style and demographic characteristics in the high-tech Kun-Shan region of Mainland China using the leader Behavior Description Questionnaire (LBDQ).
\end{abstract}

\section{INTRODUCTION}

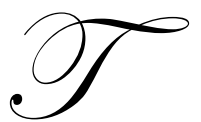

aiwan is a long, narrow island that stretches from north to south and is often described as being similar in appearance to a yam. It is only half the geographical size of Tasmania, one of many Australian islands. According to experts, the economic strength of Taiwan has made it a central world player significant enough to activate a global recession if undermined. Taiwanese companies, sharing the same language and culture with the Mainland attracted by the cheap raw material and labor force in China, have become enthusiastic in investing in China.

The China Heat — a fanatical investment trend in China — has become more common among Taiwanese manufacturing companies as China also starts to open its market to the global society. Furthermore, the forming of vertical industrial chains lowers the risk for Taiwanese companies investing in China, as their suppliers and customers are also investing in China.

One of the concerns of the changing global economy is leadership. As time goes by, the enormous difference in results of previous studies show that leadership styles are continually changing. Additionally, the blueprint of Taiwanese economics is based on utilizing global resources with strengthened ability, developing organizational culture with typical experience, and applying suitable leadership to remake a Taiwanese economic miracle.

Moreover, in today's global society organizations have to deal with challenges as well as increasingly volatile competition. Therefore, leaders' effectiveness has become a very important issue that must be explored in order to understand how to motivate employees and help them to achieve organizational goals. Flexible leaders can be considered to be those leaders who choose the appropriate style for the appropriate situation. According to Yukl (1989), Situational Leadership ${ }^{\circledR}$ Theory is naturally engaging and popular with practicing managers in such areas as research and development, communications, project management, health care, and education. However, direct research has only provided weak support for the theory. Vecchio (1987) conducted a comprehensive study found strong support for this theory in the low readiness groups. However, he was unable to determine the best style for the moderate readiness group.

The results of research to date regarding the validity of the Situational Leadership ${ }^{\circledR}$ Model as a theory are mixed, with the model receiving only partial support for its explanatory validity as a theory of leadership (Fernadez \& Vecchio, 1997). In consideration of the weak research support for the model's utility as a theory, Hersey now refers to the Situational Leadership ${ }^{\circledR}$ Model as an applications model of leadership (Schermerhorn, 1997). The model can be used to guide workers to become more effective by providing them with basic ideas concerning flexibility in how they 
interact with followers based on differing follower characteristics. This is in contrast to using the model as a theory of leadership intended to fully explain leadership dynamics.

\section{PURPOSE OF THE STUDY}

The purpose of this study was to investigate the relationship between Taiwanese executives' leadership style and demographic characteristics in the high-tech Kun-Shan region of Mainland China using the Leader Behavior Description Questionnaire (LBDQ). Due to cultural factors in Taiwan, various demographic features were scrutinized for their relationship with the primary variables of this research.

\section{HYPOTHESIS OF THE STUDY}

Demographic variables (gender, age, level of education, executive position in the company, years with the present company, years of leadership with the present company, and years of total leadership with all companies) and executives' leadership styles are not significantly correlated.

\section{LITERATURE REVIEW}

\section{Development Of Leadership Theory}

Most leadership research focused only on the leader's past personality and actions; because of the quickly changing environment, understanding the current effectiveness of the organization is a huge challenge. Current leadership research changed the orientation to leadership style. Robinson (1993) defined leadership style as “... the characteristic manner in which a person behaves in attempting to influence the actions or beliefs of others, particularly subordinates" (p. 7).

Nowadays, leadership is defined as a process that creates, and is the result of, relationships that focus on the interactions of both leaders and coworkers, not just the competencies of leaders. In the future, leaders will need to build their understanding of the process of leadership, become conversant with doing business internationally, and conceive of strategies on a global scale.

\section{Leadership Eras}

There are three main eras which comprise leadership theory. The trait era of leadership is considered to be the period from the late 1800s to the mid-1940s. The trait theory attempted to identify specific physical, mental, and personality characteristics associated with leadership success, and it relied on research that related various traits to certain success criteria. The trait theory is alive and well. Researchers (Bryman, 1992; Kirkpatrick \& Locke, 1991; Bass, 1990) have seen resurgence in interest in the trait approach including studies on how traits influence leadership and play a role in determining leadership ability and effectiveness. Kirkpatrick and Locke said that "it is unequivocally clear that leaders are not like other people" (p. 59). Bass stated that individual factors of successful leadership could be classified into six groups: capacity, achievement, responsibility, participation, status, and situation.

The behavior era began in the late 1940s when researchers began to explore the idea that how a person acts determines that person's leadership effectiveness because simply analyzing the leaders' traits cannot provide enough information about leadership effectiveness. They examined behaviors and their impact on measures of effectiveness such as production and the satisfaction of followers. Leadership behavior can be studied by analyzing what leaders do in relation to accomplishing tasks and maintaining the efforts of people performing the tasks. Leadership, as the behaviors of a leader, is connected to guiding group activities (Hemphill, 1957).

During this period, the famous Ohio State staff developed the Leader Behavior Description Questionnaire (LBDQ) to gather leaders' behavioral data. This instrument is used to describe how leaders carry out their activities and contains 15 items pertaining to initiating structure and 15 items pertaining to consideration. The two sets of behaviors are two different dimensions rather than two ends of the same continuum. As such, a leader can perform both sets of behaviors 
to varying degrees (Nahavandi, 2003). The behavior of a leader could be described as any mix of both dimensions (see Figure 2). The LBDQ has been employed to assess the relationship between leader behavior and a variety of indicators of effective leadership in hundreds of surveys in the last 50 years (Yukl, 2002).

The contingency era evolved in the 1960s when researchers began to believe that environmental variables played some role in leadership effectiveness. The focus of the contingency era was on the observed behavior of leaders and their followers in various situations, not on any inborn or developed ability or potential for leadership. Thus the contingency theory of leadership proposed that leadership effectiveness depended on the fit between personality, task, power, attitude, and perceptions.

The Situational Leadership ${ }^{\circledR}$ Model was developed by Paul Hersey and Kenneth Blanchard in late 1960s and purported that leader behavior is contingent upon variations in situations and that the leader should fit the leadership style to the demands of situations (Blanchard, 1985; Blanchard, Zigsrmiz, \& Nelson, 1993). Situational Leadership, originally called Life Cycle Theory, is a contingency theory that focuses on the followers. It basically views the leader-follower relationship as similar to that between a parent and child. Just as parents need to abandon control to let the child become more mature, so too should leaders (Robbins, 2001).

Situational Leadership is composed of four leadership styles in accordance with the degree of task and relationship behaviors: high task and high relationship, high task and low relationship, low task and high relationship, and low task and low relationship (Hersey, 1992). The four styles can be applied to the given situation and the followers' maturity levels. A major part of the Situational Leadership ${ }^{\circledR}$ Model is concerned with the development level of subordinates. Development level refers to the degree to which subordinates have the competencies and commitment necessary to accomplish a given task or activity (Blanchard, 1985). The two factors of followers' maturity include ability, which refers to the followers' task-relevant skills and technical knowledge, and willingness, which refers to the followers' commitment, self-confidence, and self-respect (Hersey, 1992). By combining followers' ability and willingness, four levels of follower maturity are produced to acquire the basic leadership styles:

- Telling: The followers need specific guidance when the situation results in low ability and low willingness.

- $\quad$ Selling: The followers need direct guidance when the situation results in low ability and high willingness.

- $\quad$ Participating: The followers need more to be participative when the situation results in high ability and low willingness.

- $\quad$ Delegating: The followers need to be able to accept responsibility when the situation results in high ability and high willingness. (Hersey et al., 2001).

Only a few research studies have been conducted to justify the assumptions and propositions set forth by the Situational Leadership approach. However, Situational Leadership is easy to understand, well known, and frequently used for training leaders within organizations. The intuitively appealing concept that leaders need to adjust their style to followers' abilities has made the model popular with practitioners and trainers.

\section{Transactional And Transformational Leadership}

The new leadership approach has been broadly studied to find fresh versions of effective leadership style. In the old approaches, leadership was viewed as management with the emphasis on the visions of the leader and innovation and learning in the organization. In the new approach, the focus is on motivation, inspiration, organizational commitment, empowerment, and stimulating extra effort from followers (Bryman, 1992).

Transactional leaders use rewards as their primary source of power. Followers obey the leader when the exchange meets the followers' needs. The relationship continues as long as the reward is desirable to the follower, and both the leader and the follower see the transaction as a means of advancing toward their personal goal (Bass, 1990).

However, transactional leadership by itself is not enough for today's dynamic environment. Transformational leadership is helpful in creating and supporting organizational changes. Bass (1990) defined transformational leadership as going beyond the focus on the exchange between leaders and followers to a broader view that elevates 
the interests of employees, stimulates employees to look beyond their own interests to what best benefits the group, and encourages employees to accept the organization's mission as their own. Transformational leaders may use several methods to achieve their goals, such as inspiring employees solely on the strength of personal charisma, appealing to the employee's emotional needs, or stimulating the employees intellectually.

\section{Demographics}

In reality, there are only ambiguous definitions of a leader. For example, in the United States, leaders are defined as people who are decisive, aggressive, ambitious, intolerant of poor performance, and have strong analytical skills. Jack Welch and Andy Grove are examples of two people who have magnetized a large following because their behavior is consistent with the U.S. model of good leadership. However, in Taiwan, the popular management philosophy is teamwork, market-share objectives, and a commitment to quality.

There are plenty of studies discussing executives' gender issues in the United States, including Lyness and Thompson's investigation (1997) of both the position and compensation of female executives compared with male executives. They found that although there were no significant differences in base salaries or bonuses between male and female executives, male executives had more authority than did female executives.

Moreover, women often find themselves in stereotypically feminine areas (i.e., education, health, social services) and in less powerful positions than their male colleagues when they advance to managerial and higher level positions (Burress \& Zucca, 2004). Therefore, female executives, faced with a lack of power and status in their positions, are forced to adopt a more deferential leadership style in order to get the cooperation that they require (Kanter, 1977). According to research done at the Kelley School of Business at Indiana University, the number of female executives in the United States is now lower than it was 10 years ago (Crainer \& Dearlove, 1999). In 1987, there were 11 female directors at Fortune 500 companies; by 1997, there were just eight. The number of women CEOs in these companies was two in 1987 and remains the same a decade later (Crainer \& Dearlove).

Crainer and Dearlove (1999) also mentioned that "demographic predictions in the United States suggest that the number of 35 to 44 year olds-the traditional executive talent pool-will fall by 15 percent between 2000 and 2015 . At the same time, the number of 45 to 54-year olds-the current senior executive population-will rise" (p. 22). Baby boomers in the United States represent an aging workforce and an aging executive population because of a surplus of middle managers in the 1980s.

In addition to gender and age, level of education is an important factor that may affect an executive. Swinyard and Bond (1980) conducted a study of executives in 1967-1976 and found that subjects with a master's of business administration (MBA) degree got their executive positions at a younger age (44 years old) than those without MBAs (47). "New CEOs through this period increasingly relied more heavily on human capital as evidenced by increasing educational levels and greater reliance on a specialized graduate degree, the Master's of Business Administration" (Keiser, 2004, p. 56).

Furthermore, Doyle (1995) noted “...the urgent need for executive development to promote both individual learning and organizational adaptation and renewal" (p. 7). Thus, executive education is seen as a strategic tool. Papadakis and Bourantas (1998) found that the greater information-processing capabilities of CEOs stemmed from better education.

Another interesting point is that more recent studies including high technology industries have determined that CEOs in higher technology industries are more likely to have backgrounds in research and development, and tend to be younger than CEOs in lower technology industries (Hambrick, Black, \& Fredrickson, 1992). Therefore, high levels of education are associated with favorable attitudes toward innovation, a high capacity for information processing, and tendency to do more analysis and searching for information.

\section{METHODOLOGY}


This research investigated the possible relationship between business executives' leadership styles and demographic characteristics in Taiwan; therefore, it is a correlational design. The researchers collected the following demographic information: gender, age, level of education, executive position in the company, years with the present company, years of leadership with the present company, and years of total leadership with all companies. These demographic characteri8stics were examined for their relationship with leadership style.

A quantitative approach was used in this study. Huysamen (1997) said that "descriptions of quantitative research typically discern a cycle of successive phases of hypothesis formulation, data collection, analysis and interpretation" (p. 1). In addition, a large part of data analysis of quantitative research is statistical, striving to show that the world can be looked at in terms of one reality; this reality, when isolated in context, can be measured and understood, a perspective known as positivism (Gay \& Airasian, 1999).

Using a deductive approach, quantitative research seeks to establish facts, make predictions, and test hypotheses that have already been stated. Descriptive research has been characterized as the study of the current or past status of something, such as behaviors, attitudes, and other characteristics of participants (McMillan \& Schumacher, 2001). Correlational research studies the relationship between two variables (Howell, 1999). Therefore, this was a descriptive and correlational study.

\section{Participants}

Taiwanese companies that invest in Mainland China include those investing money in local companies and those establishing various subsidiaries. The potential participants included 163 executives from 151 companies. These participants were either a board chairman; vice chairman; chief executive officer (CEO); president; vice president in charge of a principal business unit, division, or function (such as sales, administration or finance); or any other officer who performed a policy-making function, excluding those in the human resources department.

Each of the 163 executives was asked to complete the survey instrument. The researchers received direct access to the companies' executives and received approval to collect data from the organizations. Therefore, a high level of cooperation was assured.

\section{Leader Behavior Description Questionnaire (LBDQ)}

The Leader Behavior Description Questionnaire-Form XII (LBDQ-XII) was “... developed for use in obtaining descriptions of a supervisor by the group members whom he supervises" (Stogdill, 1963, p. 1). Stogdill noted that the instrument contained items describing the manner in which a leader might behave, along with the respondent rating of the way in which the leader is perceived to engage in each type of behavior. The respondents judge the frequency with which their leader engages in each form of behavior by checking one of five descriptions: always, often, occasionally, seldom, or never. Two broadly defined dimensions of behaviors, consideration and initiation of structure, were established as encompassing a wide variety of leader characteristics.

The LBDQ-XII contains 100 items that describe specific ways in which leaders behave. It represents the fourth revision of the questionnaire and includes 12 subscales; each subscale is composed of either 5 or 10 items. A subscale is essentially defined by its component items and stands for a complex pattern of behavior.

According to Hersey et al. (2001), the concepts of task behavior and relationship behavior are similar to the initiating structure and consideration of the Ohio State studies. The results can be divided into four kinds of leadership style as follows: (a) high initiating structure and low consideration is the same as telling leadership style, (b) high initiating structure and high consideration is the same as selling leadership style, (c) low initiating structure and high consideration is the same as participative leadership style, and (d) low initiating structure and low consideration is the same as delegating leadership style (Hersey et al., 2001).

\section{Data Collection}


In the primary data collection phase, the researchers used typical survey procedures, including “...planning and design, administration, data analysis, feedback and interpretation, action planning and follow-through" (Kraut, 1996). Data for this research were acquired from the survey of 163 selected Taiwanese executives from companies in the Kun-Shan area of Mainland China. The researchers also used secondary data sources, which according to Chien (2003) include "...reports, books, essays, dissertations, related periodicals, and academic journals." The third level of data sources were related to leadership theory and knowledge management including encyclopedias, dictionaries, yearbooks, and bibliographies.

\section{Data Analysis}

After collecting responses, the researchers scored the instruments and organized the data. The researchers used the Statistical Package for Social Science (SPSS) edition 12.0 for Windows 2000, which includes descriptive statistics and Pearson-product moment correlations. The alpha was set at .05 ( $\mathrm{p}=.05)$, and the confidence level was $95 \%$. It was used to examine the hypotheses about possible correlations between executives' leadership styles and their demographics. The reliability levels of the two instruments were examined using the Cronbach's alpha coefficient test.

The Pearson product-moment correlation was utilized in primary hypothesis to test whether the executives' leadership styles (selling, telling, participating, and delegating) and their demographics are or are not significantly correlated. Pearson product-moment correlation is used to analyze the relationship between two continuous and interval variables (Huang, 2000). The $t$ test was used to examine the difference between executives' demographics and different types of leadership styles used in the companies. The one-way ANOVA was used to test the difference between different demographic variables and different leadership styles.

\section{Response Rate}

Data collection was conducted Sept. 16-Dec. 2, 2004. The survey instruments were distributed to 151 companies and an executive was selected in each company. However, executives at 12 companies transferred the questionnaire to their co-workers, who are also executives in their companies. Therefore, 163 questionnaires were distributed and 85 were returned for a total response rate of 52.15\%; 78 valid surveys were returned for a valid response rate of $47.85 \%$. Sixty-six executives did not respond for a non-response rate of $40.49 \%$. In addition to the original 12 questionnaires that were regarded as missing, 7 surveys were invalid or had incomplete responses for a missing or invalid data rate of $11.66 \%$.

\section{Results}

Table 1 indicates that the Cronbach alpha coefficients were .8944 in the Leader Behavior Description Questionnaire. After supported by the Spearman-Brown prophecy formula, the reliability coefficients range to .944 and are regarded as proven reliable.

Table 1: Survey Instrument Reliability

\begin{tabular}{lcc}
\hline Survey Instruments & Cronbach $\boldsymbol{\alpha}$ & Spearman-Brown Prophecy Formula \\
\hline Leader Behavior Description Questionnaire & .8944 & .9443 \\
\hline Meaning of Cronbach Alpha Coefficients & Very Reliable & Strongly reliable \\
\hline Note. $\mathrm{N}=78$ & &
\end{tabular}

Situational Leadership Theory considers leadership along two dimensions: task behavior (initiation of structure) and relationship behavior (consideration) (Hersey et al., 2001). Hersey stated that these two dimensions produced four styles: telling, selling, participating, and delegating, depending on the high-low levels of the two dimensions. This study showed that the dimensions of consideration and initiating structure have a reliability of 0.7148 and 0.8434 , respectively, and are considered to be very reliable. 
Executives' leadership style data were collected using the LBDQ-XII, which was divided into the consideration and initiating structure dimensions. Following the methodology of Wang (2001), leadership styles were created by separating both dimensions at the mean into high and low levels. The four styles are: telling (consideration score lower than the mean, initiating structure score higher than the mean), selling (consideration score higher than the mean, initiating structure score higher than the mean), participating (consideration score higher than the mean, initiating structure lower than the mean), and delegating (consideration score lower than the mean, initiating structure lower than the mean).

As presented in Table 2, coefficients between the variables range from -.272 to .875 . They show that variables were positively or negatively correlated and that some p values were at the level of .05 or less. Both consideration and initiating structure were strongly and positively correlated with executives' title $(\mathrm{r}=.375, \mathrm{r}=.265$, respectively) and negatively correlated with education al levels $(\mathrm{r}=-.272, \mathrm{r}=-.243$, respectively).

Consideration and total years of leadership management experience were positively correlated $(r=.324)$. Initiating structure was strongly related to years of working in the company $(\mathrm{r}=.331)$ and years of leadership at the institution $(\mathrm{r}$ $=.309)$. Consideration was positively related to years of working in the company $(\mathrm{r}=.271)$ and years of leadership at the institution $(\mathrm{r}=.271)$. Therefore, the leadership dimensions had significant positive relationships with executives' title, educational level, years of working in the current company, and years of leadership in the company. Leadership dimensions also had positive relationships with executives' years of leadership in all companies.

Moreover, the telling leadership style and executives' title were significantly correlated $(r=.875)$. The selling leadership style was positively correlated with executives' age, title, years of working in the company, and total years of leadership management experience. The delegating leadership style and educational level were strongly correlated. Therefore, the primary hypothesis one was rejected.

Table 2: Pearson Correlation Between The Executives' Leadership Styles And Demographic Characteristics

\begin{tabular}{lccccccc}
\hline & Gender & Age & Title & EL & YW & YL & TY \\
\hline Consideration & -.064 & .193 & $.375^{* *}$ & $-.272^{*}$ & $.271^{*}$ & $.271^{*}$ & $.324^{* *}$ \\
Initiating Structure & .146 & .022 & $.265^{* *}$ & $-.243^{*}$ & $.331^{* *}$ & $.309^{* *}$ & .146 \\
Total Leadership & .050 & .132 & $.392^{* *}$ & $-.316^{* *}$ & $.368^{* *}$ & $.355^{* *}$ & $.288^{*}$ \\
\hline Telling & -.368 & -.526 & $.875^{* *}$ & .340 & -.256 & -.020 & .242 \\
Selling & -.214 & $.459^{*}$ & $.439^{*}$ & -.416 & $.465^{*}$ & .404 & $.604^{*}$ \\
Participating & 0 & .236 & .146 & -.454 & .233 & .290 & .278 \\
Delegating & .208 & .012 & -.042 & $-.509^{* *}$ & .029 & -.027 & .105 \\
\hline
\end{tabular}

Note. EL= Education Level. YW= Years of Working in the Company. YL= Years of Leadership at the Institution. TY= Total

Years of Seeing Leadership Management Experience. $\mathrm{N}=78 . * \mathrm{p}<.05, * * \mathrm{p}<.01$.

Research Hypothesis: There are no significant differences among executives' leadership styles and demographic characteristics.

This hypothesis was tested using the $t$ test and one-way ANOVA statistical methods. The $t$ test was used to determine if significant differences exist in executives' leadership style by gender and title. The one-way ANOVA was performed to determine if any significant differences exist in the executives' leadership styles among age, level of education, years with the present company, years of leadership with the present company, and years of total leadership with all companies.

According to Table 3, there were no women in the participating leadership style group and there were no significant differences existing in the telling $(\mathrm{t}=.537, \mathrm{p}>.05)$, selling $(\mathrm{t}=.980, \mathrm{p}>.05)$, and delegating $(\mathrm{t}=1.103, \mathrm{p}>.05)$ leadership styles by gender. Because the $\mathrm{p}$ values were greater than .05 , these data provide substantial evidence that there were no significant differences between the executives' leadership styles and gender.

Table 3: T-test For Executives' Leadership Style And Gender 


\begin{tabular}{|c|c|c|c|c|c|c|}
\hline Dimensions & Gender & Number & Mean & SD & $\mathbf{t}$ & $\mathbf{p}$ \\
\hline \multirow{2}{*}{ Telling } & Male & 9 & 80.0000 & 2.9580 & .537 & .603 \\
\hline & Female & 3 & 79.0000 & 2.0000 & & \\
\hline \multirow{2}{*}{ Selling } & Male & 16 & 25.0000 & 3.9328 & .980 & .339 \\
\hline & Female & 6 & 23.3333 & 6.6232 & & \\
\hline Participating & $\begin{array}{l}\text { Male } \\
\text { Female }\end{array}$ & $\begin{array}{c}15 \\
0\end{array}$ & - & - & - & - \\
\hline Delegating & $\begin{array}{l}\text { Male } \\
\text { Female }\end{array}$ & $\begin{array}{c}23 \\
6\end{array}$ & $\begin{array}{l}70.3478 \\
72.3333\end{array}$ & $\begin{array}{l}3.9498 \\
3.8297\end{array}$ & 1.103 & .280 \\
\hline
\end{tabular}

Note. $\mathrm{N}=78$

As Table 4 shows, there were no significant differences among the telling $(\mathrm{t}=.59, \mathrm{p}>.05)$, participating $(\mathrm{t}=.533, \mathrm{p}$ $>.05)$, and delegating $(\mathrm{t}=.220, \mathrm{p}>.05)$ leadership styles among executive titles. However, the selling leadership style showed significant differences among executive titles $(\mathrm{t}=2.182, \mathrm{p}<.05)$.

Table 4: T-test For Executives' Leadership Style And Title

\begin{tabular}{|c|c|c|c|c|c|c|}
\hline Dimensions & Title & Number & Mean & SD & $\mathbf{t}$ & $\mathbf{p}$ \\
\hline \multirow{2}{*}{ Telling } & CEO & 3 & 79.6667 & 2.0817 & .59 & .954 \\
\hline & D-Manager & 9 & 79.7778 & 2.9907 & & \\
\hline \multirow{2}{*}{ Selling } & CEO & 14 & 88.2143 & 3.4234 & 2.182 & $.041 *$ \\
\hline & D-Manager & 8 & 85.2500 & 2.2520 & & \\
\hline \multirow{2}{*}{ Participating } & CEO & 8 & 79.7500 & 6.7135 & .533 & .603 \\
\hline & D-Manager & 7 & 78.2857 & 2.9277 & & \\
\hline \multirow{2}{*}{ Delegating } & CEO & 5 & 70.4000 & 4.7749 & .220 & .828 \\
\hline & D-Manager & 24 & 70.8333 & 3.8636 & & \\
\hline
\end{tabular}

Note. $\mathrm{N}=78$. D-Manager $=$ Department Manager

Table 5 shows there were no significant differences existing in the telling $(F=.746, p>.05)$, selling $(F=2.177, p$ $>.05)$ and participating $(\mathrm{F}=1.779, \mathrm{p}>.05)$ leadership styles by educational level. Only delegating leadership style had significant differences with executives' educational level $(\mathrm{F}=4.559, \mathrm{p}>.05)$.

Table 5: ANOVA For Executives' Leadership Style On Educational Level

\begin{tabular}{|c|c|c|c|c|c|c|}
\hline Dimensions & & SS & df & MS & $\mathbf{F}$ & $\mathbf{p}$ \\
\hline \multirow{3}{*}{ Telling } & Between Groups & 11.417 & 2 & 5.708 & .746 & .501 \\
\hline & Within Groups & 68.833 & 9 & 7.648 & & \\
\hline & Total & 80.250 & 11 & & & \\
\hline \multirow{3}{*}{ Selling } & Between Groups & 43.360 & 2 & 21.680 & 2.177 & .141 \\
\hline & Within Groups & 189.231 & 19 & 9.960 & & \\
\hline & Total & 232.591 & 21 & & & \\
\hline \multirow{3}{*}{ Participating } & Between Groups & 85.733 & 2 & 42.867 & 1.779 & .211 \\
\hline & Within Groups & 289.200 & 12 & 24.100 & & \\
\hline & Total & 374.933 & 14 & & & \\
\hline \multirow{3}{*}{ Delegating } & Between Groups & 113.027 & 2 & 56.514 & 4.559 & $.020 *$ \\
\hline & Within Groups & 322.283 & 26 & 12.396 & & \\
\hline & Total & 435.310 & 28 & & & \\
\hline
\end{tabular}

Note. $\mathrm{N}=78$

Table 6 demonstrates that there were no significant differences among age with respect to telling $(\mathrm{F}=.239, \mathrm{p}>.05)$, participating $(\mathrm{F}=.188, \mathrm{p}>.05)$ and delegating $(\mathrm{F}=.125, \mathrm{p}>.05)$ leadership styles. Selling leadership style had significant differences with executives' age $(\mathrm{F}=6.182, \mathrm{p}<.05)$. 
Table 6: ANOVA For Executives' Leadership Style On Age Group

\begin{tabular}{|c|c|c|c|c|c|c|}
\hline Dimensions & & SS & df & MS & $\mathbf{F}$ & $\mathbf{p}$ \\
\hline \multirow{3}{*}{ Telling } & Between Groups & 4.050 & 2 & 2.025 & .239 & .792 \\
\hline & Within Groups & 76.200 & 9 & 8.467 & & \\
\hline & Total & 80.250 & 11 & & & \\
\hline \multirow{3}{*}{ Selling } & Between Groups & 91.691 & 2 & 45.845 & 6.182 & $.009 *$ \\
\hline & Within Groups & 140.900 & 19 & 7.416 & & \\
\hline & Total & 232.591 & 21 & & & \\
\hline \multirow{3}{*}{ Participating } & Between Groups & 11.378 & 2 & 5.689 & .188 & .831 \\
\hline & Within Groups & 363.556 & 12 & 30.296 & & \\
\hline & Total & 374.933 & 14 & & & \\
\hline \multirow{3}{*}{ Delegating } & Between Groups & 4.144 & 2 & 2.072 & .125 & .883 \\
\hline & Within Groups & 431.167 & 26 & 16.583 & & \\
\hline & Total & 435.310 & 28 & & & \\
\hline
\end{tabular}

Note. $\mathrm{N}=78$

Because all $\mathrm{p}$ values were greater than .05 , this test shows that these data provide substantial evidence that there were no significant differences among executives' leadership style and years working in the company (see Table 7).

Table 7: ANOVA For Executives' Leadership Style On Years of Working In The Company Group

\begin{tabular}{|c|c|c|c|c|c|c|}
\hline Dimensions & & SS & df & MS & $\mathbf{F}$ & $\mathbf{p}$ \\
\hline \multirow{3}{*}{ Telling } & Between Groups & 8.083 & 3 & 2.694 & .299 & .826 \\
\hline & Within Groups & 72.167 & 8 & 9.021 & & \\
\hline & Total & 80.250 & 11 & & & \\
\hline \multirow{3}{*}{ Selling } & Between Groups & 47.058 & 3 & 15.686 & 1.522 & .243 \\
\hline & Within Groups & 185.533 & 18 & 10.307 & & \\
\hline & Total & 232.591 & 21 & & & \\
\hline \multirow{3}{*}{ Participating } & Between Groups & 40.133 & 3 & 13.378 & .440 & .729 \\
\hline & Within Groups & 334.800 & 11 & 30.436 & & \\
\hline & Total & 374.933 & 14 & & & \\
\hline \multirow{3}{*}{ Delegating } & Between Groups & 11.158 & 3 & 3.719 & .219 & .882 \\
\hline & Within Groups & 424.153 & 25 & 16.966 & & \\
\hline & Total & 435.310 & 28 & & & \\
\hline
\end{tabular}

Note. $\mathrm{N}=78$

As Table 8 shows, there were significant differences existing among years of leadership in the company with respect to telling $(\mathrm{F}=4.084, \mathrm{p}=.05)$ and selling leadership styles $(\mathrm{F}=3.124, \mathrm{p}<.05)$. There were no significant differences existing between years of leadership in the company and participating $(F=1.434, p>.05)$ and delegating $(F=.125, p$ $>$.05) leadership styles.

Table 8: ANOVA For Executives' Leadership Style On Years Of Leadership In The Company 


\begin{tabular}{|c|c|c|c|c|c|c|}
\hline Dimensions & & SS & df & MS & $\mathbf{F}$ & $\mathbf{p}$ \\
\hline \multirow{3}{*}{ Telling } & Between Groups & 48.550 & 3 & 16.183 & 4.084 & $.050 *$ \\
\hline & Within Groups & 31.700 & 8 & 3.963 & & \\
\hline & Total & 80.250 & 11 & & & \\
\hline \multirow{3}{*}{ Selling } & Between Groups & 98.543 & 4 & 24.636 & 3.124 & $.043^{*}$ \\
\hline & Within Groups & 134.048 & 17 & 7.885 & & \\
\hline & Total & 232.591 & 21 & & & \\
\hline \multirow{3}{*}{ Participating } & Between Groups & 105.400 & 3 & 35.133 & 1.434 & .286 \\
\hline & Within Groups & 269.533 & 11 & 24.503 & & \\
\hline & Total & 374.933 & 14 & 5.580 & & \\
\hline \multirow{3}{*}{ Delegating } & Between Groups & 16.740 & 3 & 5.580 & .333 & .801 \\
\hline & Within Groups & 418.571 & 25 & 16.743 & & \\
\hline & Total & 435.310 & 28 & & & \\
\hline
\end{tabular}

Note. $\mathrm{N}=78$

Table 9 presents the significant differences of telling and selling leadership styles on years of leadership in all companies $(\mathrm{F}=4.082, \mathrm{p}<.05)$. The $\mathrm{p}$ values of participating and delegating leadership styles were all greater than .05 ; therefore, there were no significant differences between these two leadership styles and years of leadership in all companies.

Table 9: ANOVA For Executives' Leadership Styles On Years of Leadership In All Companies

\begin{tabular}{|c|c|c|c|c|c|c|}
\hline Dimensions & & SS & df & MS & $\mathbf{F}$ & $\mathbf{p}$ \\
\hline \multirow{3}{*}{ Telling } & Between Groups & 14.217 & 2 & 7.108 & .969 & .416 \\
\hline & Within Groups & 66.033 & 9 & 7.337 & & \\
\hline & Total & 80.250 & 11 & & & \\
\hline \multirow{3}{*}{ Selling } & Between Groups & 94.167 & 3 & 31.380 & 4.082 & $.022 *$ \\
\hline & Within Groups & 138.424 & 18 & 7.690 & & \\
\hline & Total & 232.591 & 21 & & & \\
\hline \multirow{3}{*}{ Participating } & Between Groups & 29.933 & 3 & 9.978 & .318 & .812 \\
\hline & Within Groups & 345.000 & 11 & 31.364 & & \\
\hline & Total & 374.933 & 14 & & & \\
\hline \multirow{3}{*}{ Delegating } & Between Groups & 13.810 & 3 & 4.603 & .273 & .844 \\
\hline & Within Groups & 421.500 & 25 & 16.860 & & \\
\hline & Total & 435.310 & 28 & & & \\
\hline
\end{tabular}

\footnotetext{
Note. $\mathrm{N}=78$
}

Some significant differences were found between executives' leadership style and demographic characteristics. Therefore, the research hypothesis was rejected. In addition, the Student-Newman-Keuls (S-N-K) follow-up procedure was used when the one-way ANOVA produced significant findings. The S-N-K analysis was performed to determine which groups were significantly different based on executives' leadership style.

There was a significant difference among executives' telling leadership style and years of leadership in the company. In this case, there was a significant finding in the overall ANOVA, F = 4.084, p =.05 (see Table 9). Therefore, the S-N$\mathrm{K}$ was used to determine individual differences between each of the possible category comparisons for years of leadership in the company. The differences were between the executives' years of leadership category of 3-5 years (M $=84.0000)>1-2$ years $(M=78.0000)=11-15$ years $(M=78.5000)=6-10$ years $(M=79.6000)$. There were significant differences among executives' selling leadership style according to their title, age, years of leadership in the company, and total years of leadership management experience. 
Table 9: F-Value And p-Value Of Executives' Demographic Characteristics Under Selling Leadership Style

\begin{tabular}{lcccc}
\hline Leadership Style & Title & Age & $\begin{array}{c}\text { Years of Leadership } \\
\text { in the Company }\end{array}$ & $\begin{array}{c}\text { Total Years of } \\
\text { Leadership in All } \\
\text { Companies }\end{array}$ \\
\hline Selling & $\mathrm{t}=2.182$ & $\mathrm{~F}=6.182$ & $\mathrm{~F}=3.124$ & $\mathrm{~F}=4.082$ \\
& $\mathrm{p}<.05$ & $\mathrm{p}<.05$ & $\mathrm{p}<.05$ & $\mathrm{p}<.05$ \\
\hline
\end{tabular}

Note. $\mathrm{N}=78$

The differences were between the executives' title category of CEO $(\mathrm{M}=88.2143)>$ department manager $(\mathrm{M}=$ $85.2500)$ and the executives' age category of 50 years and older $(M=90.0000)>30-39$ years $(M=86.8000)=40-49$ years $(\mathrm{M}=85.3000)$.

Additionally, the differences were between the executives' years of leadership in the company category of 6-10 years $(\mathrm{M}=84.5000)<3-5$ years $(\mathrm{M}=86.1667)<1-2$ years $(\mathrm{M}=88.0000)<11-15$ years $(\mathrm{M}=89.5714)=15$ years and more $(\mathrm{M}=90.0000)$. Also, the differences were between the executives' total years of leadership in all companies category of 15 years and more $(M=90.1429)>6-10$ years $(M=85.5000)=11-15$ years $(M=85.6000)=1-5$ years $(\mathrm{M}=86.3333)$.

There was a significant difference among executives' delegating leadership style based on educational level. In this case, because the overall ANOVA showed that $\mathrm{F}=4.559, \mathrm{p}<.05$, the $\mathrm{S}-\mathrm{N}-\mathrm{K}$ was used to determine individual differences between each of the possible category comparisons for educational level. The differences were between the executives' educational level category of college or under $(\mathrm{M}=75.0000)>$ university $(\mathrm{M}=71.0500)=$ master's or doctorate $(M=67.6667)$.

\section{DISCUSSION AND CONCLUSION}

The significant findings of this study were that the Taiwanese executives in the Kun-Shan area of Mainland China used the delegating leadership style most frequently, followed by the selling leadership style, then the participating style, and finally the telling style. The results show that most executives recognized their own leadership style as either low consideration/low initiating structure or high consideration/high initiating structure.

\section{Chinese Cultural Influences}

Chinese culture has obvious rules of behavior that are derived from Confucian teaching (Littrell, 2002). It can be argued that the values and prescriptions of these teachings are instilled in Chinese children, even if explicit reference is not made to Confucian texts. The rules of guanxi are prescribed by Lun, as a set of Chinese feudal ethics that define the hierarchical relationships between the noble and the humble, the close and the distant, as well as the individual and the group. Specifically, the three cardinal guides (ruler guides subject, father guides son, and husband guides wife) and the five constant virtues (benevolence, righteousness, propriety, wisdom, and fidelity) work as the traditional ethical codes that still prescribe the differentiations among role relationships.

Indeed, the idea of Confucianism guided Chinese for almost several thousands years. It encouraged people to open their minds and accept something new. In Taiwan, the close trade links between various businesses and the West has meant a cross-cultural exchange and has been a means for the spreading and acceptance of Western values in Taiwanese society. Taiwanese culture is based upon Confucian values so that some management concepts are different from those found in Western culture (Punnett, 1995). Different cultures may require different management styles, and Chinese values do affect some organizational behavior of Taiwanese leaders and their subordinates (Silverthorne \& Wang, 2001). The identification of effective managers is a critical task facing all organizations, so any tools that can be identified and used to facilitate this process will greatly assist all organizations. 


\section{Executives' Leadership Styles And Their Demographics}

In this research, executives' leadership styles had positive correlation with their working title, years of working in the company, years of leading in the company, and years of total leadership in all companies. However, leadership styles had a negative correlation with executives' educational level.

A top business executive can expect members of a management team to act as a cohesive unit. Over time a selfselection process becomes evident by which only those who embrace certain norms and perspective are willing or allowed to stay in an organization (Pfeffer, 1983). The longer an executive is at a company, the more pronounced his or her leadership style becomes. Allen and Cohen (1969) found that background and work experiences in an organization shape the ways that people process information. Katz (1982) pointed out that those managers are likely to depend increasingly on their past experiences and routine information sources rather than on new information with growing organizational experience.

Moreover, research suggests that homogeneity on length of time of leading in the organization can lead to similar interpretation of events (Allen \& Cohen, 1969; Lawrence \& Lorsch, 1967) and a common vocabulary (Rhodes, 1991), and can enhance communication among group members (March \& Simon, 1958; Zenger \& Lawrence, 1989). Additionally, Hambrick and Mason (1984) said that a manager's personal experiences and values can be concluded from demographic categories such as years of experience. These factors can influence executives' leadership styles.

It is interesting to note that college undergraduates were likely to have more obvious leadership styles than those with further training after a 4-year university degree. Work experiences of the former can serve as a significant tool in helping managers develop higher-level thinking and management skills.

Significant differences were found in executives' demographics. CEOs were more likely to prefer using a selling leadership style than department managers; people who are older than 50 were more likely to prefer using a selling leadership style than others; people who have more experience in leading prefer using a selling leadership style; and people whose education level is less than college prefer using a delegating leadership style.

After thousands of years Confucianism and feudal dynasties, Chinese people are obedient, concerned about and cooperative with others, and good at predicting others' moods by observing their expressions and their behaviors. For the most part, Chinese culture strongly emphasizes respectfulness and adaptability. It also encourages people to avoid conflict and be cooperative. These basic concepts lead most Chinese to have flexible attitudes and to value commitment and cooperation. Redding (1990) said that based on the traditional Chinese approach to management, it could be predicted that the telling and selling styles of leadership would predominate. In this study, 22 of 78 executives (28\%) used the selling leadership style.

As this research shows, older, more experienced executives and those in higher positions prefer to use a leadership style that is high in consideration and initiating structure (selling). Few executives used the telling style in the current research; however, Ryan and Avery (2002) studied the leadership styles used by managers across countries and found that Australian managers avoid using the telling leadership style (low consideration and high initiating structure).

Many leadership practitioners and scholars (Bass, 1985; Kreiner, 1999) have proposed that followers need leadership to inspire them and enable them to enact revolutionary change in today’s organizations. Situational Leadership ${ }^{\circledR}$ style is intuitively appealing and popular with practicing managers in such areas as business, research and development, communications, project management, health care, and education (Yukl, 1989).

\section{REFERENCES}

1. $\quad$ Bass, M. B. (1985). Leadership and performance beyond expectations. New York: Free Press.

2. Bass, M. B. (1990). Bass \& Stogdill's handbook of leadership: Theory, research, and managerial applications (3rd ed.). New York: Free Press.

3. Blanchard, K. H. (1985). SLII: A situational approach to managing people. Escondido, CA: Blanchard 
Training and Development.

4. Blanchard, K. H., Zigarmi, D., \& Nelson, R. (1993). Situational leadership after 25 years: A retrospective. Journal of Leadership Studies, 1(1), 22-36.

5. Bryman, A. (1992). Charisma and leadership in organizations. London: Sage.

6. Burress, J. H., \& Zucca, L. J. (2004). The gender equity gap in top corporate executive positions. Mid American Journal of Business. 19, 55-63.

7. Chien, M. (2003). Leadership style and employees' organizational commitment: An exploration study of managers and employees of Hsin-Zhu Science Park. Doctoral Dissertation, University of the Incarnate Word, San Antonio, TX.

8. Crainer, S. \& Dearlove, D. (1999). Death of executive talent. Management Review, 88(7), 16-24.

9. Doyle, M. (1995). Organizational transformation and renewal: A case for reframing management development? Personnel Review, 24(6), 6-19.

10. Gay, L. R. \& Airasian, P. (1999). Educational research: Competencies for analysis and application. (6th ed.). Upper Saddle River, NJ: Merrill.

11. Halpin, A. W. (1957). Manual for the leader behavior description questionnaire. Columbus, OH: Ohio State University.

12. Hambrick, D. C. \& Mason, P. A. (1984). Upper echelons: the organization as a reflection of its top managers. Academy of Management Review, 9(2), 193-207.

13. Hambrick, D. C., Black, S., \& Fredrickson, J. W. (1992). Executive leadership of the high technology firm: What is special about it? In L. R. Gomez-Meija \& M. W. Lawless (Eds.), Top management and effective leadership in high technology (pp. 255-271). Greenwich, CT: JAI Press.

14. Hersey, P. (1992). The situational leader (4th ed). Escondido, CA: Center for Leadership Studies.

15. Hersey, P., Blanchard, K. H., \& Johnson, D. E. (2001). Management of organizational behavior: Leading human resource (8th ed.). Upper Saddle River, NJ: Prentice-Hall.

16. Howell, D. C. (1999). Fundamental statistics for the behavioral sciences (4th ed.). Pacific Grove, CA: Duxbury.

17. Huang, G. G. (2000). SPSS and comments on statistical theories. Taiwan, Taipei: Song Gang Publication.

18. Huysamen, G. K. (1997). Parallels between qualitative research and sequentially performed quantitative research. South African Journal of Psychology, 27, 1-8.

19. Kanter, R. M. (1977). Men and women of the corporation. New York: Basic.

20. Katz, D. (1982). The effects of group longevity on project communication and performance. Administrative Science Quarterly, 27(1), 81-104.

21. Keiser. J. D., (2004). Chief Executives from 1960-1989: A trend toward professionalization. Journal of Leadership \& Organizational Studies, 10(3), 52-69.

22. Kirkpatrick, S. A. \& Locke, E. A. (1991). Leadership: Do traits matter? The Executive, 5, 48-60.

23. Kraut, A. (1996). Organizational surveys: Tool for assessment and change. San Francisco: Jossey-Bass.

24. Kreiner, K. (1999). Knowledge and mind: The management of intellectual resources. Advances in Managerial cognition and organizational information processing, 6, 1-29.

25. Lawrence, P. \& Lorsch, J. (1967). Leadership and organizational performance: A study of large corporations. American Sociological Review, 37(1), 117-130.

26. Littrell, R. F. (2002.) Desirable leadership behaviors of multi-cultural managers in China. The Journal of Management Development, 21(1), 5-74.

27. Lyness, K. S. \& Thompson, D. E. (1997). Above the glass ceiling? A comparison of matched samples of female and male executives. Journal of Applied Psychology, 82, 359-375.

28. March, J. G. \& Simon, H. A. (1958). Organizations. New York: Wiley.

29. McMillan, J. H. \& Schumacher, S. (2001). Research in education (5th ed.). New York: Addison Wesley Longman.

30. Nahavandi, A. (2003). The art and science of leadership. Upper Saddle River, NJ: Prentice Hall.

31. Papadakis, V. \& Bourantas, D. (1998). The chief executive officer as corporate champion of technological innovation: An empirical investigation. Technology Analysis \& Strategic Management, 10(1), 89-110.

32. Pfeffer, J. (1983) Organizational demography. Research in Organizational Behavior, 5, $299-357$.

33. Punnett, B. J. (1995.) Preliminary considerations of Confucianism and needs in the PRC, Journal of Asia Pacific Business, 1, 25-42. 
34. Redding, S. G. (1990.) The spirit of Chinese capitalism. Berlin, Germany: De Gruyter.

35. Rhodes, R. (1991). Theory and methods in British public administration: the view from political science. Political Studies, 39(5), 533-554.

36. Robbins, S. P. (2001). Organizational behavior (9th ed.). Upper Saddle River, NJ: Prentice-Hall.

37. Robinson, G. H. (1993). A study of the relationship of leadership styles of principals and teacher job satisfaction. Unpublished doctoral dissertation, University of Arkansas, Fayetteville, AR.

38. Ryan, J. \& Avery, G. A. (2002.) Applying situational leadership in Australia. The Journal of Management Development. 21, 242-263.

39. Schermerhorn, J. (1997). Situational leadership: Conversations with Paul Hersey. Mid-American Journal of Business 12(2), 5-12.

40. Silverthorne, C. \& Wang, T. (2001). Style as a predictor of success and productivity among Taiwanese business organizations. Journal of Psychology, 135(4), 399-413.

41. Stogdill, R. M. (1963). Manual for the leader behavior description questionnaire- Form XII. Columbus, OH: Bureau of Business Research, Ohio State University.

42. Swinyard, A. W. \& Bond, F. A. (1980). Who gets promoted? Harvard Business Review. 19(1). 5-15.

43. Wang, C. L. (2001). 高雄市政府機關首長領導行為之研究 [ Research on government chief officers' leadership style in Kao-Hsiung City]. 國立中山大學中山學術研究所碩士論文.

44. Yukl, G. A. (1989). Leadership in organizations (2nd ed.). Englewood Cliffs, NJ: Prentice-Hall.

45. Yukl, G. A. (2002). Leadership in organizations (5th ed.). Upper Saddle River, NJ: Prentice Hall.

46. Zenger, T. R. \& Lawrence, B. S. (1989). Organizational demography: The differential effects of age and tenure distributions on technical communication. Academy of Management Journal, 3(32), 353-376. 